NBER WORKING PAPER SERIES

\title{
MANAGERS, INVESTORS, AND CRISES: MUTUAL FUND STRATEGIES IN EMERGING MARKETS
}

\author{
Graciela Kaminsky \\ Richard K. Lyons \\ Sergio Schmukler \\ Working Paper 7855 \\ http://www.nber.org/papers/w7855 \\ NATIONAL BUREAU OF ECONOMIC RESEARCH \\ 1050 Massachusetts Avenue \\ Cambridge, MA 02138 \\ August 2000
}

\begin{abstract}
We thank the following for valuable comments: Jeff Frankel, Mike Gavin, Michael Gibson, George Hoguet, Andrew Karolyi, Federico Sturzenegger, and participants at the World Bank/Universidad Torcuato Di Tella conference on Integration and Contagion (June 1999), the Cancun Meeting of the Econometric Society, the Latin American Economic Association, and the IDS-U. of Sussex. For help with data we thank the World Bank (East Asia and Pacific Region), Erik Sirri from the SEC, Konstantinos Tsatsaronis from the BIS, and Ian Wilson from Emerging Market Funds Research. For excellent research assistance we thank Jon Tong, Sergio Kurlat, Cicilia Harun, Jose Pineda, and Allen Cheung. (The efforts of Sergio Kurlat and especially Jon Tong were prodigious.) For financial support we thank the NSF and the World Bank (Latin American Regional Studies Program and Research Support Budget). The views expressed herein are those of the authors and not necessarily those of the National Bureau of Economic Research.

(C) 2000 by Graciela Kaminsky, Richard K. Lyons, and Sergio Schmukler. All rights reserved. Short sections of text, not to exceed two paragraphs, may be quoted without explicit permission provided that full credit, including (C) notice, is given to the source.
\end{abstract}


Managers, Investors, and Crises: Mutual Fund Strategies in Emerging Markets

Graciela Kaminsky, Richard K. Lyons, and Sergio Schmukler

NBER Working Paper No. 7855

August 2000

JEL No. F3, G1, G2

\begin{abstract}
This paper addresses the trading strategies of mutual funds in emerging markets. The data set we develop permits analysis of these strategies at the level of individual portfolios. Methodoloically, a novel feature is our disentangling the behavior of managers from that of underlying investors. For both managers and investors, we strongly reject the null hypothesis of no momentum trading: funds' momentum trading is positive - they systematically buy winners and sell losers. Contemporaneous momentum trading (buying current winners and selling current losers) is stronger during crises, and stronger for fund investors than for fund managers. Lagged momentum trading (buying past winners and selling past losers) is stronger during non-crisis, and stronger for fund managers. Investors also engage in contagion trading, i.e., they sell assets from one country when asset prices fall in another.
\end{abstract}

Graciela Kaminsky

Department of Economics

George Washington University

Washington, DC 20052

graciela@gwu.edu

Sergio Schmukler

The World Bank

1818 H Street, NW

Washington, DC 20433

sschmukler@worldbank.org
Richard K. Lyons

Haas School of Business

U.C. Berkeley

Berkeley, CA 94720-1900

and NBER

lyons@haas.berkeley.edu 


\section{Managers, Investors, and Crises: Mutual Fund Strategies in Emerging Markets}

\section{Introduction}

Financial crisis in 1997 engulfed not only Asia, it spread to countries as distant as South Africa, the Czech Republic, and Brazil. To understand why, a literature has developed that examines why the spreading of crisis might be due to financial links. There is evidence that banks, for example, were important in spreading the 1997 crisis. The transmission channel was lending: countries were exposed to the same banks (Kaminsky and Reinhart 1999). Portfolio investors have also been scrutinized, particularly institutions, such as hedge funds, pension funds, and mutual funds (Brown et al. 1998, Eichengreen and Mathieson 1998, Kim and Wei 1999, Frankel and Schmukler 1998, among many others). A common conclusion is that institutions sometimes panic, disregarding fundamentals, and spreading crisis even to countries with strong fundamentals. The literature notes that individuals, too, can contribute to this panic by fleeing from funds-particularly mutual funds-forcing fund managers to sell when fundamentals do not warrant selling.

This paper contributes to this literature on financial links by examining the trading strategies of an important class of investor: U.S. mutual funds. Surprisingly, systematic analysis of mutual funds' international strategies does not yet exist. ${ }^{1}$ Consequently, our results are of more general interest than our crisis motivation might suggest. At the same time, the lack of systematic analysis of funds' behavior during crises warrants special attention. Though there is some evidence that funds help crisis to spread, that evidence is indirect and highly aggregative. Frankel and Schmukler (1998), for example, use closedend mutual funds to show that the Mexican crisis in 1994 was not transmitted to Asia directly, but indirectly, via New York, where the funds are traded. The opposite view-

\footnotetext{
${ }^{1}$ Funds' domestic (U.S.) strategies have been analyzed extensively, however. See Grinblatt et al. (1995), Warther (1995), and Wermers (1999), among others.
} 
that funds do not spread crisis-also has some support in aggregate data. For example, net redemption by mutual-fund investors during crisis periods is not large, and outflows that occur tend to be small and short-lived (at least during Mexico's crisis-see Marcis et al. 1995 and Rea 1996). Froot et al. (1998) present a similar picture based on aggregated flows that mix mutual funds with other types of international investor. They find that net inflows during the Mexican and Asian crises decreased, but there is little evidence of net outflows. $^{2}$

Our paper departs from the more aggregated analysis above by effecting analysis at the portfolio level. We develop a novel data set that includes individual portfolios, which allows us to examine trading strategies at much higher resolution. The data include the quarterly holdings of 13 mutual funds from April 1993 to January 1999. All 13 funds are dedicated Latin America funds. (At year-end 1998, there were 25 Latin America funds; the 13 we track account for $88 \%$ of the value of these 25 funds.) We use these data to address two sets of questions. The first set relates to whether funds engage in momentum trading-systematically buying winning stocks and selling losing stocks (Jegadeesh and Titman 1993, Grinblatt et al. 1995). The second set of questions relates to whether funds engage in contagion trading, by which we mean systematically selling stocks from one country when stock prices are falling in another. In addressing this second set of questions, we establish a first, direct empirical link between contagion and trading strategies.

The methodological contribution of the paper is our approach to attributing actions to fund managers versus underlying investors. Despite a vast literature on the behavior of domestic (i.e., U.S.) funds, to our knowledge we are the first to disentangle the two. In effect, the trades of mutual funds reflect both institutional and individual decisions. To understand those trades, particularly in the international context, ensuring that the decisions are not commingled is an important step.

\footnotetext{
2 Though a lovely data set, the Froot el al. (1998) data do not include transactions settled in foreign currencies, e.g., ADR trades in New York and Brady bonds. These trades can be especially important in times of crisis when local-market liquidity is at a minimum. For Latin American countries, the importance of these trades extends to non-crisis periods as well-for many stocks, more trading occurs in New York as ADRs than on the local market. Our fund-portfolio data include all trades.
} 
Our results show that emerging-market funds do indeed engage in momentum trading. Their strategies exhibit positive momentum - they systematically buy winners and sell losers. This is due to momentum trading at both the fund-manager level and the investor level (through redemptions/inflows). We further distinguish between contemporaneous momentum trading (buying current winners and selling current losers) and lagged momentum trading (buying past winners and selling past losers). Contemporaneous momentum trading is stronger during crises, and stronger for fund investors than for fund managers. Lagged momentum trading, on the other hand, is stronger during non-crisis periods, and stronger for managers. We also find that funds engage in contagion trading, by which we mean that they systematically sell assets from one country when asset prices fall in another. This contagion trading is due primarily to underlying investors, not managers.

The paper is organized as follows. The next section outlines our approach to measuring momentum trading and contagion trading. Section III describes our data. Section IV presents our momentum and contagion results. Section V addresses whether return autocorrelation within Latin America can rationalize our section-IV results. Section VI concludes. The appendix provides some related regression-based analysis.

\section{Strategies: Momentum Trading and Contagion Trading}

This section presents our approach to testing whether funds employ momentum and contagion trading strategies. Momentum trading-also called positive feedback trading - is the systematic purchase of stocks that have performed well, and sale of stocks that have performed poorly ("winners" and "losers"). Contagion trading is the selling of assets from one country when asset prices are falling in another. Contagion trading is thus a cross-country phenomenon, in contrast to momentum trading, which is a within-country phenomenon. (This type of cross-country analysis is not possible using recent singlecountry data sets, such as those of Kim and Wei 1999 and Choe, Kho, and Stulz 1999.)

First, we review the existing finance literature on momentum trading. Second, we present our approach to testing for momentum trading, an approach that draws from this 
earlier literature. Then we turn to contagion trading, presenting first a brief review of the "contagion" literature, followed by our approach to testing for contagion trading. The approach we adopt in testing for contagion trading is in the same spirit as our test for momentum trading.

\section{II.1. Introduction to Momentum Trading}

The literature on momentum trading includes two lines of work, one based in asset pricing and the other based in international finance. The asset-pricing line begins with the finding that a strategy of buying past winners and selling past losers generates significant positive returns over 3- to 12-month holding periods (Jegadeesh and Titman 1993, Asness et al. 1997, Rouwenhorst 1998). ${ }^{3}$ Once established, this result inspired work on whether investors actually follow momentum trading strategies. Grinblatt et al. (1995), for example, examine the domestic strategies of U.S. mutual funds and find that they do systematically buy past winners. They do not systematically sell past losers, however. They also find that funds using momentum trading strategies realize significantly better performance. Evaluation of performance is a central theme for all the papers in this assetpricing line of the literature.

The second line of work on momentum trading is based in international finance. Its organizing theme is the link between returns and international capital flows. At the center of this literature is the positive contemporaneous correlation between capital inflows and returns. Early work establishes this correlation using data aggregated over both time and types of market participant (Tesar and Werner 1994, Bohn and Tesar 1996). Later work relaxes the aggregation over time to address whether the contemporaneous correlation in quarterly data is truly contemporaneous (Froot et al. 1998, Choe et al. 1999, Kim and Wei 1999). Higher frequency data can distinguish three possibilities. Returns may precede

\footnotetext{
${ }^{3}$ The return "continuations" that are implied by this result are not inconsistent with the return "reversals" documented elsewhere in the literature. Horizon length is the key to understanding this: continuations appear at mid-range horizons, 3 to 12 months. Return reversals, in contrast, appear at short horizons (up to 1 month, see Jegadeesh 1990 and Lehmann 1990) and at long horizons (3 to 5 years, see De Bondt and Thaler 1985). Reversals call for "contrarian" (or negative feedback) trading strategies. Parenthetically, all these time-series anomalies are distinct from the cross-sectional anomalies that have received much attention in the asset-pricing literature recently (e.g., size and book-to-market effects).
} 
flows, indicating positive feedback trading (which is not necessarily irrational, per the asset-pricing literature noted above). Returns and flows may be truly contemporaneous, indicating that order flow itself may be driving prices. ${ }^{4}$ And returns may lag flows, indicating flows' ability to predict returns. Using high-frequency data aggregated across types of market participant, Froot et al. (1998) find evidence of all three, with the firstpositive feedback trading - being the most important for explaining quarterly correlation. Choe et al. (1999) and Kim and Wei (1999) use high-frequency data from Korea to examine positive feedback trading around the 1997 currency crisis. Choe et al. find that foreign investors as a group engage in positive feedback trading before the crisis, but during the crisis feedback trading mostly disappears. Kim and Wei examine foreign institutional investors separately and find that they engage in positive feedback trading at all times—before, during, and after the crisis.

Our analysis is related to, and borrows from, both the international-finance and asset-pricing lines of the literature. Like the work in international finance, we are more concerned about international flows and crisis transmission than portfolio performance. Like work in asset pricing, however, we maintain a direct link to investment strategy and its measurement. In particular, we focus on a specific class of international investormutual funds. A benefit of focusing on a specific investor class is that we can characterize the evolution of actual portfolios, and how that evolution relates to returns in various countries. Another benefit is that our data allow us to analyze jointly the behavior of fund managers and their underlying investors. On the cost side, focusing on funds as a specific investor class means that we lose resolution in terms of data frequency: our data are quarterly.

\footnotetext{
${ }^{4}$ Microstructure finance provides three channels for truly contemporaneous price impact. The first is information-if the buyer has superior information about a security's payoffs, then the purchase signals that information, shifting expectations, and thereby increasing price. The second is incomplete risksharing at the marketmaker level - the buyer's purchase temporarily disturbs the marketmaker's position, which requires the buyer to pay compensation in the form of a higher price (so-called "inventory effects"). The third is imperfect substitutability - the buyer's purchase may be a large enough portfolio shift relative to the market as a whole that permanently higher price is required to clear the market (even if it is common knowledge that the buyer does not have superior information about the security's payoffs).
} 


\section{II.2. Measuring Momentum Trading}

Our momentum-trading measure is akin to that used to analyze funds' domestic strategies (e.g., Grinblatt et al. 1995). The measure captures the relation between security transactions and returns. It is based on the mean of individual observations of the variable: ${ }^{5}$

$$
M_{i, j, t}=\left(\frac{Q_{i, j, t}-Q_{i, j, t-1}}{\bar{Q}_{i, j, t}}\right) R_{j, t-k},
$$

where $\mathrm{Q}_{\mathrm{i}, \mathrm{j}, \mathrm{t}}$ is the holding by fund $\mathrm{i}$ of stock $\mathrm{j}$ (in shares) at time $\mathrm{t}, \overline{\mathrm{Q}}_{\mathrm{i}, \mathrm{j}, \mathrm{t}}$ is $\left(\mathrm{Q}_{\mathrm{i}, \mathrm{j}, \mathrm{t}}+\mathrm{Q}_{\mathrm{i}, \mathrm{j}, \mathrm{t}-\mathrm{l}}\right) / 2$, and $\mathrm{R}_{\mathrm{j}, \mathrm{t}-\mathrm{k}}$ is the return on stock $\mathrm{j}$ from $\mathrm{t}-\mathrm{k}-1$ to $\mathrm{t}-\mathrm{k}$. When $\mathrm{k}=0$, this measure captures the contemporaneous relation between trades and returns-referred to as lag-zero momentum trading (LOM). When $\mathrm{k}=1$, the measure captures the lagged response of trades to returns, and is referred to as lag-one momentum trading (L1M). Parenthetically, notice the implication of the $\mathrm{j}$ subscript: the mean of $\mathrm{M}_{\mathrm{i}, \mathrm{j}, \mathrm{t}}$ measures the intensity of momentum trading at the level of individual stocks. Testing the null of no momentum trading is a test of whether the mean of $\mathrm{M}_{\mathrm{i}, \mathrm{j}, \mathrm{t}}$ over all $\mathrm{i}, \mathrm{j}$, and $\mathrm{t}$ is zero.

This measure of momentum trading has two important advantages. First, it is not contaminated by "passive price momentum." Passive price momentum arises in momentum trading measures - like those of Grinblatt et al. - where the term in brackets is a change in portfolio weight, rather than a percentage quantity adjustment. When using a portfolio weight, a price increase in one stock (relative to prices of other holdings) produces a positive relation between weights and returns that has nothing to do with trading strategy. (A similar positive relation arises for losing stocks.) The second advantage of our measure over one based on portfolio weights is that our measure is not contaminated by another passive effect - "passive quantity momentum." When using portfolio weights, a large trade in one stock can have substantial effects on the weights of holdings that involve no

\footnotetext{
${ }^{5}$ This mean estimate does not value-weight the individual stock positions. This could make a difference if the intensity of momentum trading differs depending on position value. After calculating it both ways, we did not find any qualitative difference in the results.
} 
transactions. Our main concern here-as in the rest of the international-finance-based literature on momentum trading - is the relation between returns and transaction flows. ${ }^{6}$ Accordingly, we want our realizations of $\mathrm{M}_{\mathrm{i}, \mathrm{j}, \mathrm{t}}$ to reflect actual transactions- the buying and selling of winners and losers.

\section{Separating Manager and Investor Momentum Trading}

An important issue in the context of mutual-fund strategies is the effect of net redemptions. Many funds experience substantial redemptions during crisis periods. If, on average, funds sell shares to meet redemptions when $R_{j, t-k}$ is negative, then our momentum trading measures will be positive. This result is not spurious. But it does reflect strategies of underlying investors, rather than strategies of the fund manager.

We control for this redemption effect by measuring the quantity transacted in each stock relative to a fund-specific benchmark. This benchmark reflects the quantity that would be transacted if a fund's net flows from investors produced proportional adjustment in all stocks. Specifically, to isolate the manager's contribution to momentum trading we calculate individual observations of:

$$
M_{i, j, t}^{\prime}=\left(\frac{Q_{i, j, t}-Q_{i, j, t-1}}{\bar{Q}_{i, j, t}}-\frac{\sum_{j \in i}\left(Q_{i, j, t}-Q_{i, j, t-1}\right) \bar{P}_{j, t}}{\sum_{j \in i} \bar{Q}_{i, j, t} \bar{P}_{j, t}}\right) R_{j, t-k}
$$

where $\mathrm{P}_{\mathrm{j}, \mathrm{t}}$ is the price of security $\mathrm{j}$ at time $\mathrm{t}$, and $\overline{\mathrm{P}}_{\mathrm{j}, \mathrm{t}}$ is $\left(\mathrm{P}_{\mathrm{j}, \mathrm{t}}+\mathrm{P}_{\mathrm{j}, \mathrm{t}-1}\right) / 2$. The second term in brackets is a term that is fund-specific, i.e., for a given fund $\mathrm{i}$ and time $\mathrm{t}$, it is invariant across stocks $\mathrm{j}$. It captures the percent increase in portfolio size due to net inflows. Here, we use the notation $\mathrm{j} \in \mathrm{i}$ to denote all those stocks $\mathrm{j}$ held by fund $\mathrm{i}$. The overall momentum trading measure in equation (2) therefore reflects the degree to which the manager of fund i buys winners and sells losers beyond any average quantity adjustment due to fund

\footnotetext{
${ }^{6}$ This contrasts with the asset-pricing-based literature on momentum, whose main concern is portfolio performance, in which case it is necessary to consider the return impact of all portfolio positions. Note too
} 
inflows/outflows. To understand why, note that the numerator of the second term in brackets is the change in portfolio value due to inflows/outflows-using the $\overline{\mathrm{P}}_{\mathrm{j}, \mathrm{t}}$ term factors out capital gains/losses - and the denominator is the average portfolio value. (As with our first momentum trading measure $\mathrm{M}_{\mathrm{i}, \mathrm{j}, \mathrm{t}}$, when $\mathrm{k}=0 \quad \mathrm{M}_{\mathrm{i}, \mathrm{j}, \mathrm{t}}^{\prime}$ captures the contemporaneous relation between trades and returns-L0M-and when $\mathrm{k}=1 \quad \mathrm{M}_{\mathrm{i}, \mathrm{j}, \mathrm{t}}^{\prime}$ captures the lagged response of trades to returns-L1M). Under the null hypothesis of no momentum trading at the manager level, the mean of the observations $\mathrm{M}_{\mathrm{i}, \mathrm{j}, \mathrm{t}}^{\prime}$ is zero.

We can also examine the investor-level term in isolation. That is, we can calculate individual observations of

$$
M_{i, j, t}^{\prime \prime}=\left(\frac{\sum_{j \in i}\left(Q_{i, j, t}-Q_{i, j, t-1}\right) \bar{P}_{j, t}}{\sum_{j \in i} \bar{Q}_{i, j, t} \bar{P}_{j, t}}\right) R_{j, t-k} .
$$

Henceforth, we refer to momentum trading statistics calculated from equations (1)-(3) as whole-fund, manager-only, and investor-only momentum, respectively.

\section{A Second Investor-Level Measure}

Before moving on, it is important to recognize what our investor-only measure is capturing, and what it is not capturing. What our investor-only measure does capture is investor effects on our whole-fund measure; that is, the sum of the investor-only and manager-only measures equals the whole-fund measure. (This is not quite true in our reported results because we omit some outlier observations for robustness, as described below in section IV.) Though this investor-only measure is certainly an object of interest, it does not recognize that investors' decisions are made at the level of the fund, not at the level of individual stocks. (Manager decisions, in contrast, are made at the level of individual stocks). To capture this, we also estimate an investor-only measure at the fund level. Specifically, we estimate the mean of the statistic:

that emerging-market funds are subject to large and rapid redemptions which, depending on liquidity in specific markets, can produce significant passive quantity momentum. 


$$
M_{i, t}^{\prime \prime \prime}=\frac{\sum_{j \in i}\left(Q_{i, j, t}-Q_{i, j, t-1}\right) \bar{P}_{j, t}}{\sum_{j \in i} \bar{Q}_{i, j, t} \bar{P}_{j, t}} R_{i, t-k}
$$

where $\mathrm{R}_{\mathrm{i}, \mathrm{t}-\mathrm{k}}$ is the change in fund i's Net Asset Value (NAV) in period t-k. Clearly, this reduces the number of observations-we lose the stock dimension-but it better corresponds to the decision that investors actually face.

\section{Conditional Momentum Trading}

In addition to the momentum measures LOM and L1M, we are also interested in conditional momentum trading. Specifically, we split our sample into sub-periods: crisis and non-crisis. The crisis portion of our full sample (April 1993 to January 1999) includes four sub-periods: December 1994 to June 1995 (Mexico), July 1997 to March 1998 (Asia), August 1998 to October 1998 (Russia), and January 1999 (Brazil). ${ }^{7}$

\section{Statistical Inference}

Several inference issues deserve further attention. First, the percentage quantity changes - the term in brackets in equations (1) through (4) - may have fund-specific volatilities. Two factors could account for differing volatilities at the fund level. Factor one is the considerable cross-sectional difference in fund size-size can affect trading strategies. Factor two is fund differences that are distinct from size, such as turnover ratios, redemption penalties, and other factors. Below, we test for heteroskedasticity across funds $i$, and after finding it, we correct for it. ${ }^{8}$

\footnotetext{
${ }^{7}$ We also examined a second conditional momentum measure by splitting our sample into buys and sells (as in Grinblatt et al. 1995). Buying past winners and selling past losers need not be symmetric. We found, however, that our results were extremely sensitive to the specification of expected returns, an adjustment that is necessary when splitting buys from sells (see Grinblatt et al., page 1091). We do not report those results due to their fragility.

${ }^{8}$ Because our heteroskedasticity correction affects only standard errors, each observation of $\mathrm{M}_{\mathrm{i}, \mathrm{j}, \mathrm{t}}$ gets equal weight in the calculation of a momentum measure's mean. Our correction for heteroskedasticity therefore does not alter the fact that funds with more observations have more effective weight. Regrettably, we have little statistical power to explore whether funds differ appreciably in the intensity of their
} 
While the first inference issue pertained to heterogeneity across funds, a second inference issue pertains to dependence across observations within funds. Specifically, individual observations of our various momentum trading statistics, $\mathrm{M}_{\mathrm{i}, \mathrm{j}, \mathrm{t}}$, are unlikely to be independent across stocks within a given fund. Our mean estimate should account for this cross-stock, within-fund correlation. Our estimates of the mean cluster observations within funds, and allow the weights assigned to individual observations to vary with the covariance structure.

A third inference issue that warrants attention is the possibility that our momentum trading measures might be biased due to high return volatility, which is clearly a feature of our crisis-ridden sample (see Forbes and Rigobon 1998). In fact, we are not exposed to this bias under our null, because under our null the statistics we report in Tables 1-5 are equal to zero. In this case the bias is not problematic. ${ }^{9}$

\section{II.3. Introduction to Contagion}

The financial crises of the 1990s in Europe, Mexico, Asia, Russia, and Brazil spread rapidly across countries, including countries with diverse market fundamentals. ${ }^{10}$ These events spawned a literature to make sense of the seeming "contagion." The term contagion is used quite differently by different authors, however, so let us be more specific. From the outset, however, it was clear that authors use that term quite

momentum trading. As for heteroskedasticity in the time-series dimension, our sample partition into crisis and non-crisis periods accounts for the most obvious correction.

${ }^{9}$ Under the alternative hypothesis of non-zero measures, however, precise statistical comparisons across crisis and non-crisis sub-samples would require adjustments for the volatility-specific nature of the sample split. This type of comparison is not central to our paper. Nevertheless, we did re-estimate our main comparative results with a Forbes-Rigobon correction (in this case, a correction to estimated covariance, rather than correlation), and found no qualitative change in the results. (Note, too, that the regression results we report in the appendix are not subject to this potential bias.)

${ }^{10}$ Witness Indonesia in 1997. Nobody can disagree that there were signs of weakness in the Indonesian economy at the outset of the Asian crisis: the banking sector was fragile, the economy was not growing, and there was a current account deficit. Still, these problems were not insurmountable. Kaminsky (1998), for example, estimates that the probabilities of crisis in Indonesia by June 1997 amounted to only 20 percent. This probability stands in sharp contrast to the likelihood of a currency crisis in Thailand, which skyrocketed to 100 percent at the beginning of 1997. Still, the Indonesian rupiah collapsed only weeks after the floating of the Thai baht. 
differently. Presently, the literature on contagion identifies three types: fundamentalspillover contagion, common-cause contagion, and non-fundamental contagion. Fundamental-spillover contagion occurs when an inside disturbance is rapidly transmitted to multiple, economically interdependent countries. Common-cause contagion occurs when an outside disturbance is rapidly transmitted to multiple countries (e.g., a fall in commodity prices, or learning about common fundamental factors). Fundamental disturbances underlie both of these first two types. The third type-non-fundamental contagion - can stem from any kind of disturbance; the defining characteristic is that the rapid transmission to multiple countries is beyond what is warranted by fundamentals (i.e., controlling for fundamentals cannot account for it). This third type is sometimes referred to as pure or true contagion.

Many authors focus on the first two types of contagion, those driven by fundamentals. For example, Eichengreen, Rose, and Wyplosz (1996) examine whether contagion is more prevalent among countries with either important trade links or similar market fundamentals. In the first case, devaluation in one country reduces competitiveness in partner-countries, prompting devaluations to restore competitiveness (fundamentalspillover contagion). In the second case, devaluation acts like a wake-up call: investors seeing one country collapsing learn about the fragility of "similar" countries, and speculate against those countries' currencies (common-cause contagion). The Eichengreen et al. evidence points in the direction of trade links rather than similar fundamentals. Corsetti et al. (1998) also claim that trade links drive the strong spillovers during the Asian crisis. Kaminsky and Reinhart (1999) focus instead on financial-sector links. In particular, they examine the role of common bank lenders and the effect of cross-market hedging (a type of common-cause contagion). They find that common lenders were central to the spreading of the Asian crisis (as they were to the spreading of the Debt Crisis of the 1980s).

The non-fundamental category of contagion has attracted more attention than the two fundamentals-driven categories. Theoretical work on non-fundamental contagion focuses on rational herding. For example, in the model of Calvo and Mendoza (1998), the costs of gathering country-specific information induce rational investors to follow the 
herd. In the model of Calvo (1999), uninformed investors replicate selling by liquiditysqueezed informed investors because the uninformed mistakenly (but rationally) believe these sales are signaling worsening fundamentals. Kodres and Pritsker (1999) focus on investors who engage in cross-market hedging of macroeconomic risks. In that paper, international market comovement can occur in the absence of any relevant information, and even in the absence of direct common factors across countries. For example, a negative shock to one country can lead informed investors to sell that country's assets and buy assets of another country, increasing their exposure to the idiosyncratic factor of the second country. Investors then hedge this new position by selling the assets of a third country, completing the chain of contagion from the first country to the third.

The literature on non-fundamental contagion also has an empirical branch. Kaminsky and Schmukler (1999) find that spillover effects unrelated to market fundamentals are quite common, and spread quickly across countries within a region. Valdes (1998) examines the degree to which comovement of Brady-bond prices is unexplained by fundamentals. Interestingly, contagion in his paper is symmetric, applying both on the downside during crises and on the upside during periods of rapid capital inflow. A different line of empirical work on non-fundamental contagion examines whether crises are spread by particular investor groups. For example, Choe, Kho, and Stulz (1998) use transaction data in the Korean equity market to examine whether foreign investors destabilize prices. They find evidence of herding by foreign investors before Korea's economic crisis in late 1997, but these effects disappear during the peak of the crisis, and there is no evidence of destabilization. Since their data include only transactions on the Korean Stock Exchange, these authors cannot examine the transmission of crisis across countries.

\section{II.4. Measuring Contagion Trading}

Our approach to testing for contagion is different from the literature reviewed above. Data on individual portfolios allow us to address contagion in a new way-from the trading-strategy perspective. We will use the term contagion trading to mean the 
systematic selling (buying) of stocks in one country when the stock market falls (rises) in another. $^{11}$

To do this we introduce a new measure-a contagion trading measure. Our contagion trading measure is based on the methodology outlined above for measuring momentum trading. Like the momentum measures, we present contagion trading measures at three different levels: whole-fund contagion trading (C), manager-only contagion trading $\left(\mathrm{C}^{\prime}\right)$, and investor-only contagion trading $\left(\mathrm{C}^{\prime \prime}\right)$. These three measures are the sample averages of the variables:

$$
\begin{gathered}
C_{i, j, t}=\left(\frac{Q_{i, j, t}-Q_{i, j, t-1}}{\bar{Q}_{i, j, t}}\right) R_{f, t} \\
C_{i, j, t}^{\prime}=\left(\frac{Q_{i, j, t}-Q_{i, j, t-1}}{\bar{Q}_{i, j, t}}-\frac{\sum_{j \in i}\left(Q_{i, j, t}-Q_{i, j, t-1}\right) \bar{P}_{j, t}}{\sum_{j \in i} \bar{Q}_{i, j, t} \bar{P}_{j, t}}\right) R_{f, t} \\
C_{i, j, t}^{\prime \prime}=\left(\frac{\sum_{j \in i}\left(Q_{i, j, t}-Q_{i, j, t-1}\right) \bar{P}_{j, t}}{\sum_{j \in i} \bar{Q}_{i, j, t} \bar{P}_{j, t}}\right) R_{f, t} \cdot
\end{gathered}
$$

Instead of testing for a relation between quantity changes and own-stock returns, our contagion trading measure tests for a relation between quantity changes and foreigncountry equity returns. In effect, we are testing for what might be called "cross-country momentum trading." Here, $\mathrm{R}_{\mathrm{f}, \mathrm{t}}$ is the return on the foreign-country index $\mathrm{f}$ from $\mathrm{t}-1$ to $\mathrm{t}$. For each of the three measures above $\left(\mathrm{C}, \mathrm{C}^{\prime}\right.$, and $\left.\mathrm{C}^{\prime \prime}\right)$, we consider five different contagion

\footnotetext{
${ }^{11}$ Notice that this definition does not take account of the fundamental-versus-non-fundamental distinction introduced above. The appendix introduces a regression-based approach that allows us to test for contagion with controls for various fundamental factors.
} 
trading measures, each one constructed from a different foreign equity index. Those foreign equity indexes include Brazil, Mexico, Asia, Russia, and the U.S. Naturally, when calculating the contagion trading measure when $\mathrm{f}=$ Brazil, we do not include observations where stock $\mathrm{j}$ is from Brazil (similarly for Mexico). Under the null hypothesis of no contagion trading, the mean of the observations $\mathrm{C}_{\mathrm{i}, \mathrm{j}, \mathrm{t}}$ is zero.

Our contagion trading measure in equations (5)-(7) allows us to address many of the issues we address with our momentum trading measure. For example, we examine crisis versus non-crisis sub-samples, and we partition the crisis sub-sample further to isolate the effects of particular crises. We do not offer a contagion-trading analogue to equation (4) —investor-only at the fund level—only because the results we shall find for that measure are, in the end, similar to the investor-only results from equation (7).

\section{Data}

Our data on mutual-fund holdings come from two sources. The first source is the U.S. Securities and Exchange Commission (SEC). Mutual funds are required to report holdings to the SEC twice a year. The second source is Morningstar. Morningstar conducts surveys of mutual fund holdings at a higher frequency: quarterly surveys are the norm for most funds. For our purposes, quarterly data are available from Morningstar for about $50 \%$ of the funds we examine. In those instances where our measure of $\mathrm{M}_{\mathrm{i}, \mathrm{j}, \mathrm{t}}$ is based on portfolio holdings that are not measured three months apart, these observations of $\Delta \mathrm{Q}_{\mathrm{i}, \mathrm{j}, \mathrm{t}}$ are multiplied by $3 / \mathrm{x}$, where $\mathrm{x}$ is the number of months between $\mathrm{Q}_{\mathrm{i}, \mathrm{j}, \mathrm{t}}$ and $\mathrm{Q}_{\mathrm{i}, \mathrm{j}, \mathrm{t}-\mathrm{1}}$.

Our sample includes the holdings of 13 Latin America equity funds (open-end) from April 1993 to January 1999 (24 quarters). Those funds are (1) Fidelity Latin America, (2) Morgan Stanley Dean Witter Institutional Latin America, (3) Van Kampen Latin America (formerly Morgan Stanley), (4) BT Investment Latin America Equity, (5) TCW Galileo Latin America Equity, (6) TCW/Dean Witter Latin America Growth, (7) Excelsior Latin America, (8) Govett Latin America, (9) Ivy South America, (10) Scudder Latin America, (11) T. Rowe Price Latin America, (12) Merrill Lynch Latin America, and 
(13) Templeton Latin America. Not all of these funds existed from the beginning of our sample; on average we have about 10 quarters of data (out of a possible 24) per fund.

Our third source of data is Bloomberg and the International Finance Corporation (IFC). Bloomberg provides monthly price series for all equities held by the 13 funds, including ADRs. (The need for monthly price data arises in our analysis of lag-one momentum trading.) These price series are corrected for splits and dividends. The IFC provides information on stock market indexes, which we need for our contagion trading analysis. Our contagion trading analysis uses the IFC Latin America Stock Market index, the IFC Asia Stock Market index, and several IFC country stock market indexes. The U.S. equity return is the S\&P 500 return. All return data are expressed in percent.

\section{Results: Momentum and Contagion Trading}

We present our results in four parts. First, we present aggregate evidence on the trades of mutual funds in times of crisis. Then, we present results on within-country momentum trading (equations 1-4). We follow these with cross-country contagion trading results (equations 5-7). In the appendix, we also present some regression-based results relating momentum and contagion trading with other determinants of trading strategy.

\section{IV.1. Aggregate Evidence on our Sample of Funds During Crisis}

Though our data set does include individual portfolios, let us first consider evidence based on the aggregation of those portfolios. We focus this aggregate evidence on funds' experience with investor inflows and outflows. During the fourth quarter of 1997-the peak of the Asian crisis_-Latin American funds suffered large outflows (Figure 1). ${ }^{12}$ The reversal from inflows to outflows during the Asian and Russian crises is more severe than that during the Mexican crisis in December 1994. In the Mexican crisis, funds tended to pull out of Mexico, Argentina, and Brazil, all of which are relatively liquid;

\footnotetext{
${ }^{12}$ Net selling in Figure 1 is calculated as the change in number of shares-as a percentage of average shares held during the quarter-valued at the beginning-of-quarter price. The average shares held during the quarter is the mean of the beginning- and end-of-quarter holdings.
} 
funds tended not to pull out from more illiquid markets, such as Colombia. Moreover, the Mexico-induced pullout was temporary-by the third quarter of 1995 fund inflows to Latin America had resumed (consistent with the findings of Marcis et al. 1995 and Rea 1996). Relative to the Mexican crisis, the Asian and Russian crises of 1997 and 1998 were more broad-based and persistent. In those crises the retreat from Latin America was more indiscriminate, with heavy sales reaching even the most illiquid markets. On average, net sales in 1998 were about 32 percent. This result differs from that of Froot et al. (1998), who find little evidence of net outflows during the Asian crisis. A possible explanation is that the aggregated data used by Froot et al. include institution types that counteract the clear net selling by mutual funds (hedge funds?). Another possible explanation is that the Froot el al. data do not include transactions settled in dollars, euros, or yen, e.g., ADR trades in New York and dollar denominated bonds. This is very important in Latin America. Our data set includes all these trades.

One technique available to managers is using "cash" (e.g., liquid money-market instruments such as U.S. Treasury bills) to buffer their portfolios from redemptions. Holding cash allows managers to meet redemptions without the need to sell less-liquid assets. In principle, this can mute the effect of investor outflows on the underlying stocks. However, managers can also reinforce investors' actions if they increase their liquid positions in times of investor retrenchment. For our whole sample, funds kept an average of 4.4 percent of their net asset value in cash. We then split our sample into two subsamples, one where on average these funds received inflows, and one where on average these funds suffered outflows. In the inflows sub-sample we find an average cash position of 4.6 percent, whereas in the outflow sample we find an average cash position of 4.3 percent. Average cash positions are remarkably stable. Managers' choice of cash position does not appear to either mute or reinforce investor actions. ${ }^{13}$

13 A natural question is whether these cash positions are stable because managers face some kind of constraint. The reality is that funds are far less constrained than our cash-holding results might indicate in any de jure sense. De facto, however, managers are sensitive about departing too much from their benchmarks. The classic example is the hapless manager at Fidelity's Magellan Fund in the late 90s who felt that the stock market was over-valued, switched heavily into cash, watched the market rise further, and was fired for the decision. 


\section{IV.2. Momentum Trading Results}

In our full sample, we find strong evidence of lag-zero momentum trading at all three levels: whole-fund, manager-only, and investor-only (Table 1, column 1). Interestingly, contemporaneous momentum trading is especially strong during crises. In terms of attribution, it is investors that account for the lion's share of the contemporaneous momentum trading at the whole-fund level. Significant lag-one momentum trading is present only in the non-crisis portion of our sample, and it is concentrated at the manager level. ${ }^{14}$ For robustness, we estimate each cell based only on observations of $\mathrm{M}_{\mathrm{i}, \mathrm{j}, \mathrm{t}}$ within three standard deviations of its mean. This is the reason why, within any column of Table 1, the manager-only and investor-only estimates do not sum to the whole-fund estimate exactly. ${ }^{15}$

To interpret the size of the coefficients, consider the whole-fund LOM estimate of 2.36. Given the units of our data, an LOM estimate of 2.5 implies that on average the product of $\left(\Delta \mathrm{Q}_{\mathrm{i}, \mathrm{j}, \mathrm{t}} / \overline{\mathrm{Q}}_{\mathrm{i}, \mathrm{j}, \mathrm{t}}\right)$ and $\mathrm{R}_{\mathrm{j}, \mathrm{t}}$ over a quarter is 2.5 percent (a representative example would be a return of $-10 \%$ and a position reduction of 0.25 , or $2.5 \%) .{ }^{16}$

Table 2 presents estimates of our investor-only measure at the fund level, rather than at the stock level as in Table 1. Recall that this fund-level variant of the investor-only measure recognizes that investors' decisions are made at the level of the fund, not at the level of individual stocks. Despite fewer observations from losing the stock dimension, our results are sharpened in terms of statistical significance, though the overall pattern remains the same. The only notable change in the pattern is the significance of L1M at the investor leve: it is now significant at the 1 percent level, whereas it was insignificant in Table 1.

Table 3 presents momentum trading measures for three crisis-period sub-samples:

\footnotetext{
${ }^{14}$ In our estimation, L1M always relates the transacted quantities between $\mathrm{t}-1$ and $\mathrm{t}$ with the return over the month preceding $\mathrm{t}-1$. Increasing the length of the period over which lagged returns are measured diminishes explanatory power, in general.

${ }^{15}$ Using all observations tends to increase both point estimates and t-statistics.

${ }^{16}$ Returns are measured in percent. The quantity-adjustment term in momentum is untransformed (e.g., the 0.25 in the example). Note that the quantity-adjustment term uses the average quantity in the denominator, so that the position reduction in our parenthetical example is only approximate. Note too that our L1M measures below are based on monthly returns, not quarterly returns as in our L0M measures, so their size is correspondingly smaller.
} 
the Mexican Crisis (December 1994 to June 1995), the Asian Crisis (July 1997 to March 1998), and the Russian Crisis (August 1998 to October 1998). The interesting question here is whether momentum trading is equally strong across different crises. The answer is no. Within our Latin American sample, we find that positive momentum trading was strongest during the 1994 Mexican Crisis.

\section{IV.3. Contagion Trading Results}

Tables 4 and 5 present our contagion trading results. Table 4 presents the allsample results, as well as the crisis versus non-crisis sub-samples. Table 5 splits the crisis sub-sample further into the Mexican, Asian, and Russian crises. In Table 4, we find more significance at the investor level than at the manager level. Thus, investors clearly engage in contagion trading, but managers are less apt. Of the five different return benchmarks (Brazil, Mexico, Asia, Russia, and the U.S.), Russia clearly has the strongest effectsfunds are systematically buying Latin American equities when Russia's returns are high, and vice versa. This is especially true during the Russian Crisis, which squares with informal accounts of the extraordinarily intense contagion at that time. Even during the Russian Crisis, however, fund managers remained cool-headed: there is no evidence they engaged in contagion trading. The contemporaneous relation with U.S. equity returns is the only one of the five return benchmarks that is concentrated at the manager level. It is also the only significant effect that is negative. This negative LOC statistic for the U.S. return implies that fund managers systematically buy Latin American equities when U.S. returns are low (controlling for fund inflows/redemptions). Though past work has shown clear links between emerging-market returns and U.S. interest rates, this is the first evidence of which we are aware that links actual portfolio shifts to U.S. equity returns.

Table 5 focuses on contagion trading during three specific crises: the Mexican, the Asian, and the Russian. The reaction of investors to Russian equity returns during the Russian crisis was particularly strong: investors systematically sold Latin American equities when Russian equity returns were low. Note, though, that this link to Russia is not operative at the manager level. In the case of the Mexican crisis, the effect is smaller, but still significant, and there is some evidence that managers were involved in that case. 
In the case of the Asian crisis, there is no discernable link to the trading of Latin American equities. The last three columns show the link to U.S. market returns during each of these three crises. Given the proximity to Mexico, and the importance of economic links between the two countries, it is not surprising that the link between Latin-American portfolios and U.S. returns is strongest during the Mexican crisis. Interestingly, the contagion trading statistic is negative, and is significant at both the manager and investor levels. This suggests that, during the Mexican crisis, managers and investors tended to sell Latin American equities when U.S. returns were high, and vice versa. One interpretation is that strong U.S. returns in the face of Mexico's crisis bodes well for Mexican equities, which induces a portfolio shift away from the rest of Latin America.

In closing this section on contagion trading, it is worthwhile re-emphasizing the qualitative difference between the results above and the existing contagion literature. The difference is that we measure quantities, as well as prices, and address their joint behavior, whereas much of the literature focuses on correlation in prices only.

\section{Rationalizing Momentum Trading: Return Autocorrelation?}

In an environment with positively autocorrelated returns, momentum trading is a natural response. The previous section presented evidence of positive LOM and, at least during non-crisis periods, positive L1M. This raises the question of whether returns within Latin America exhibit positive autocorrelation. One common way to test for return autocorrelation is using variance ratios. If returns follow a random walk, then return variance is a linear function of horizon length. That is, the variance of returns over $\mathrm{k}$ periods is $\mathrm{k}$ times the variance of returns over one-period. If instead returns are positively autocorrelated, the variance of k-period returns is larger than the sum of one-period returns-variances grow faster than linearly. Thus, variance ratios larger than one are consistent with rational positive momentum trading. Alternatively, when returns are negatively autocorrelated, the variance of k-period returns is smaller than $\mathrm{k}$ times the variance of one-period returns. Variance ratios smaller than one would call for negative momentum (or contrarian) trading. 
Table 6 reports the values of the variance-ratio test statistic at different horizons, together with p-values, for seven Latin American countries. For comparison we also provide results for the U.S. stock market. ${ }^{17}$ Interestingly, stock returns in several Latin American markets are highly persistent (variance-ratio statistics larger than one), even at three and four-year horizons. In contrast, U.S. returns show no persistence at any horizon. Though certainly not proof that the positive momentum trading we find in Latin America is rational-after all, this persistence in returns is at the index level-these results do point to the possibility of rationalizing our momentum results, at least for some countries (e.g., Mexico, Chile, Colombia, and Venezuela).

It is important to note, however, that while positive autocorrelation is necessary for rationalizing positive L1M, it is certainly not necessary for rationalizing positive LOM. As noted in Section II.1, returns and trades may be truly contemporaneous if order flow itself is driving prices. This is possible where fund transactions are "large" relative to liquidity in the market (the imperfect substitutability channel noted in footnote 4), or when fund managers' trades are perceived as containing superior information.

\section{Conclusion}

Discriminating among the various ways that financial markets can spread crisis requires a sharper picture of actual behavior. Who is doing the trading? What are their trading strategies? In this paper we examine portfolios of an important class of international investor-US mutual funds. We address two sets of questions. The first relates to whether and when these funds engage in momentum trading-systematically buying winning stocks and selling losing stocks. We find that international funds do engage in momentum trading. Their trading exhibits positive momentum, due to momentum at two levels: the fund manager level and the investor level (through redemptions/inflows). Funds also engage in momentum trading in both crisis and noncrisis periods. Contemporaneous momentum trading is stronger during crises, and stronger for fund investors than for fund managers. Lagged momentum trading, on the other hand, is stronger during non-crisis periods, and stronger for managers.

\footnotetext{
${ }^{17}$ See Campbell, Lo, and MacKinlay (1997) for the asymptotic distribution of the variance-ratio test.
} 
The second set of questions we address relates to funds' use of contagion trading strategies - selling assets from one country when asset prices fall in another. We find that funds do engage in contagion trading. Per the appendix, this result is robust to controlling for own-stock returns, the local-market factor, and the U.S.-market factor. Strictly speaking, while these controls have a sound theoretical basis, they are not sufficient to conclude that this contagion trading is non-fundamental (or pure) contagion trading. In any event, we have uncovered several stylized facts that are useful for evaluating hypotheses about the emerging-market crises and their transmission.

Beyond these stylized facts, this paper includes several methodological innovations. For example, the distinction between momentum trading at the manager and investor levels is new to the literature, as is our method for distinguishing the two. Our method of measuring contagion trading via transaction quantities is also new. Finally, our regression-based approach to controlling for systematic return factors in measuring momentum and contagion trading provides a valuable check on the bilateral measures' robustness.

An important question we have not addressed is, Who takes the other side of these momentum and contagion trades? Someone certainly must. This question is, unfortunately, beyond the feasible scope of our analysis. We can offer some parting thoughts however. Consider for example the following question: If the model in our managers' and investors' heads is one of undershooting prices, followed by positively autocorrelated returns, then must it be that their counter-parties believe the opposite model? No, this is not necessary. The literature in microstructure finance-which we touch on in section II.1-provides many models of liquidity providers who do not have opposite models or views, they simply require compensation for providing liquidity in the form of transaction costs (revenues from their perspective). It is also appropriate to keep in mind that, together, the mutual funds we examine own only about 10 percent of the market capitalization of the countries we consider. If they were a more substantial fraction, then finding counterparties for their trades would be much more difficult. Indeed, the premise that funds respond to contemporaneous returns rather than causing them would be become rather tenuous. 


\section{Appendix: A Regression-Based Approach}

The bivariate relations examined via equations (1)-(7) draw from, and therefore allow direct comparison with, past empirical work on momentum trading. But these bivariate relations provide no means of testing joint significance. Is lag-one momentum trading still significant after controlling for lag-zero momentum trading (i.e., after controlling for contemporaneous price effects)? Is cross-country contagion trading still significant after controlling for own-price effects via lag-zero and lag-one momentum trading? Are these relations robust to including local-market index returns and the U.S.market index return?

A regression-based approach provides a natural framework for addressing these questions. At the whole-fund level, the questions of the previous paragraph can be addressed by estimating:

$$
\left(\frac{Q_{i, j, t}-Q_{i, j, t-1}}{\bar{Q}_{i, j, t}}\right)=\alpha+\beta_{1} R_{j, t}+\beta_{2} R_{j, t-1}+\beta_{3} R_{L A, t}+\beta_{4} R_{L M, t}+\beta_{5} R_{U S, t}+\varepsilon_{i, j, t} .
$$

Here, $R_{j, t}$ and $R_{j, t-1}$ are own-stock returns, as before. These variables capture lag-zero and lag-one momentum trading, respectively. The variable $\mathrm{R}_{\mathrm{LA}, \mathrm{t}}$ is the contemporaneous return on a Latin American equity index. ${ }^{18}$ This variable captures cross-country contagion trading. The fourth variable, $\mathrm{R}_{\mathrm{LM}, \mathrm{t}}$, is the local-market index return. This variable does not enter the analysis introduced in the previous sections, and is intended here as a control for country-level systematic factors. The last variable, $\mathrm{R}_{\mathrm{US}, \mathrm{t}}$, is the U.S.-market index return. This variable also does not enter in the previous sections, and is intended here as a control for systematic U.S. factors, which have well established effects on emerging equity markets.

\footnotetext{
${ }^{18}$ We do not attempt to remove the own-country portion of the broader Latin American index. Note, thought, that the own-country index is also in the regression, and our results are able to distinguish quite sharply between them. In fact, the own-country index is never significant, so it is highly unlikely the effects are confounded.
} 
At the manager-only and investor-only levels, the dependent variable in equation (A1) is replaced with:

Manager-only: $\left(\frac{Q_{i, j, t}-Q_{i, j, t-1}}{\bar{Q}_{i, j, t}}\right) \rightarrow\left(\frac{Q_{i, j, t}-Q_{i, j, t-1}}{\bar{Q}_{i, j, t}}-\frac{\sum_{j \in i}\left(Q_{i, j, t}-Q_{i, j, t-1}\right) \bar{P}_{j, t}}{\sum_{j \in i} \bar{Q}_{i, j, t} \bar{P}_{j, t}}\right)$

Investor-only: $\left(\frac{Q_{i, j, t}-Q_{i, j, t-1}}{\bar{Q}_{i, j, t}}\right) \rightarrow\left(\frac{\sum_{j \in i}\left(Q_{i, j, t}-Q_{i, j, t-1}\right) \bar{P}_{j, t}}{\sum_{j \in i} \bar{Q}_{i, j, t} \bar{P}_{j, t}}\right)$

This follows the separation of the manager-only and investor-only levels in our analysis of bivariate momentum and contagion trading.

\section{$\underline{\text { Results }}$}

Tables A1-A3 present OLS estimates of the models in equations (A1), (A2), and (A3). At the whole-fund level (Table A1), the full sample generates significant positive coefficients on all of the first three variables. Thus, momentum and contagion trading are robust to moving from bivariate measures to multivariate measures, and including controls for the overall local and U.S. markets. Interestingly, the local-market control is never significant. The U.S.-market control, in contrast, is quite significant, and negative. This squares with past empirical work showing that U.S. investors tend to chase emerging markets when returns at home are low. When the sample is split into crisis and non-crisis sub-periods, we find that contagion trading is largely a crisis-period phenomenon.

Tables A2 and A3 present results for the manager-only and investor-only regressions, respectively. At the manager level, we find significant positive momentum trading (both lag zero and lag one), and significant contagion trading with respect to the U.S. market, but no evidence of contagion trading with respect to other Latin American markets $\left(\beta_{3}\right)$, except in times of crisis. Our investor-level results tell a distinctly different story. Once we control for the local index return, we find that investors do not engage in 
stock-specific momentum trading. This is not surprising: one would not expect investors to respond to individual stocks, but to the market as a whole. They do respond strongly, however, to the contemporaneous local-index return. And they also respond strongly within the quarter to other Latin American markets per the significant positive coefficient $\beta_{3}$. Note, though, that these latter two effects are concentrated in the non-crisis periods. 
Figure 1: Mutual Funds' Net Buying/Selling of Stocks in Latin America
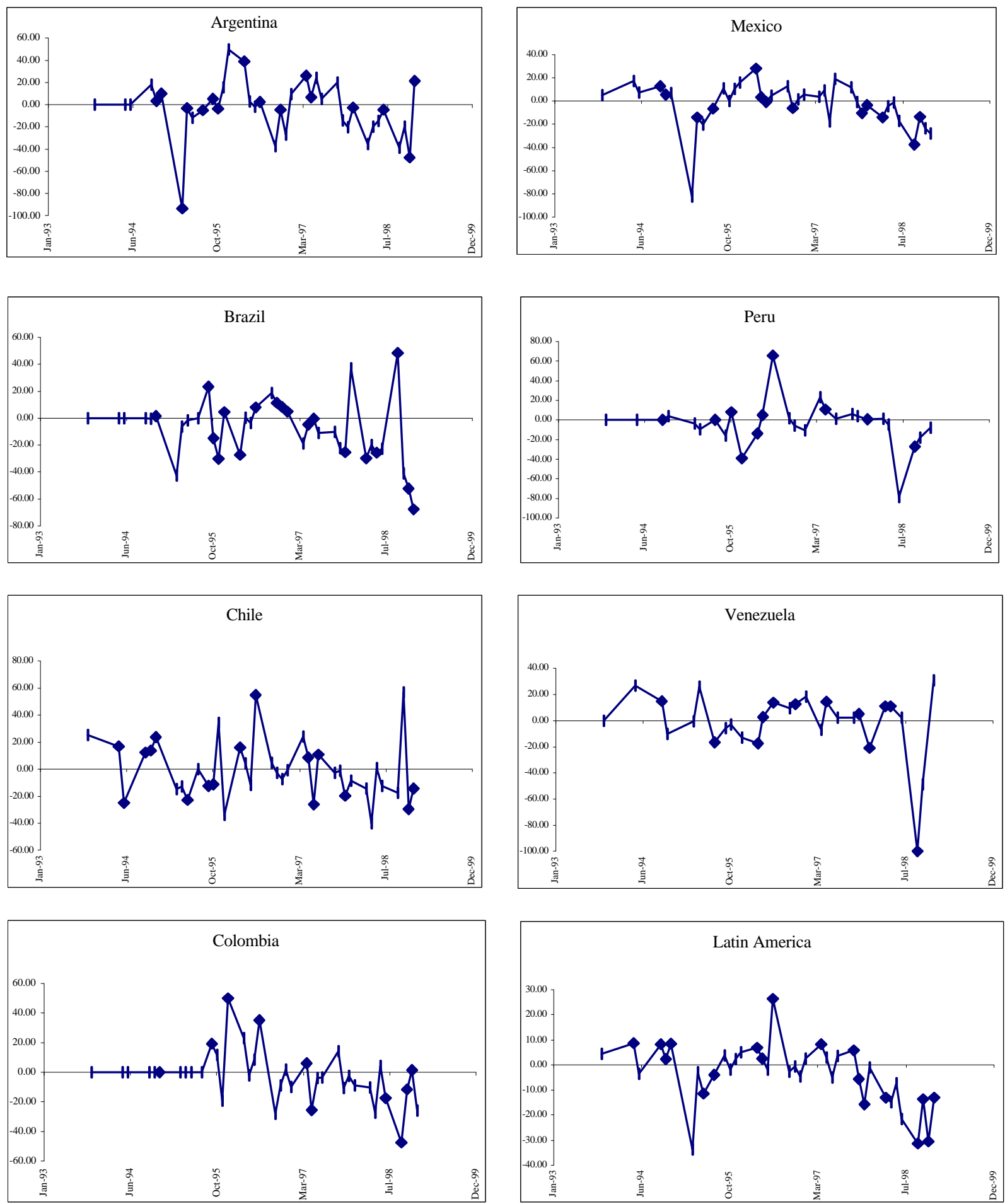

Source: Our data set. Net Buying/Selling is equal to the value-weighted percentage change in quarterly holdings of all funds in each country, where the value weighting uses the beginning-of-period share price. All figures are in percent. However, since quarterly change in the number of shares is divided by the mean number of shares (at the beginning and end-of-period), changes can be greater than 100 percent. 


\section{Table 1}

Lag-0 and Lag-1 Momentum Trading

\begin{tabular}{|c|c|c|c|}
\hline & All Sample & Non-Crisis & Crisis \\
\hline \multicolumn{4}{|c|}{ Whole-Fund Momentum } \\
\hline $\begin{array}{c}\text { L0M } \\
\text { T-statistic } \\
\text { Observations }\end{array}$ & $\begin{array}{l}2.36^{* * * *} \\
5.63 \\
4924\end{array}$ & $\begin{array}{l}0.98 * * * \\
3.19 \\
3288\end{array}$ & $\begin{array}{l}5.13 * * * \\
4.55 \\
1636\end{array}$ \\
\hline $\begin{array}{c}\text { L1M } \\
\text { T-statistic } \\
\text { Observations }\end{array}$ & $\begin{array}{c}0.20 \\
1.53 \\
4852\end{array}$ & $\begin{array}{l}0.25^{* *} \\
2.35 \\
3214\end{array}$ & $\begin{array}{l}0.11 \\
0.40 \\
1638\end{array}$ \\
\hline \multicolumn{4}{|c|}{ Manager-Only Momentum } \\
\hline $\begin{array}{c}\text { L0M } \\
\text { T-statistic } \\
\text { Observations }\end{array}$ & $\begin{array}{l}0.86^{* * * *} \\
2.90 \\
4929\end{array}$ & $\begin{array}{l}0.29 \\
1.27 \\
3287\end{array}$ & $\begin{array}{l}2.01 * * * \\
2.68 \\
1642\end{array}$ \\
\hline $\begin{array}{c}\text { L1M } \\
\text { T-statistic } \\
\text { Observations }\end{array}$ & $\begin{array}{l}0.16 \\
1.58 \\
4849\end{array}$ & $\begin{array}{l}0.18^{* *} \\
2.11 \\
3210\end{array}$ & $\begin{array}{l}0.11 \\
0.61 \\
1639\end{array}$ \\
\hline \multicolumn{4}{|c|}{ Investor-Only Momentum } \\
\hline $\begin{array}{c}\text { L0M } \\
\text { T-statistic } \\
\text { Observations }\end{array}$ & $\begin{array}{l}1.70 * * * \\
6.12 \\
4954\end{array}$ & $\begin{array}{l}0.81 \text { *** } \\
3.45 \\
3292\end{array}$ & $\begin{array}{l}3.46^{* * * *} \\
4.09 \\
1662\end{array}$ \\
\hline $\begin{array}{c}\text { L1M } \\
\text { T-statistic } \\
\text { Observations }\end{array}$ & $\begin{array}{l}0.08 \\
1.06 \\
4854\end{array}$ & $\begin{array}{l}0.05 \\
0.75 \\
3221\end{array}$ & $\begin{array}{l}0.16 \\
0.75 \\
1633\end{array}$ \\
\hline
\end{tabular}

LOM is the point estimate for the mean lag- 0 momentum trading measure. L1M is the point estimate for the mean lag- 1 momentum trading measure (measured from return over the previous month). Whole-Fund momentum tests whether the mean of $\left(\Delta \mathrm{Q}_{\mathrm{ijt}} / \overline{\mathrm{Q}}_{\mathrm{ijt}}\right) \mathrm{R}_{\mathrm{jt}-\mathrm{k}}$ is zero, per equation (1). Manager-Only momentum controls for investor redemption effects as in equation (2). Investor-Only momentum reflects only investor redemption effects as in equation (3). All t-statistics are corrected for heteroskedasticity across funds. Full sample: quarterly data from April 1993 to January 1999. The crisis portion of the sample is December 1994-June 1995, July 1997-March 1998, August 1998October 1998, and January 1999. The non-crisis portion is the rest of the sample. The total of roughly 4400 observations is 13 funds times an average of about 35 stocks per fund, times an average of about 10 quarters of available data per fund. For robustness, results in each cell are based only on observations within three standard deviations of the mean.

* $\quad$ Statistically Significant at the 10-percent level

** Statistically Significant at the 5-percent level

*** Statistically Significant at the 1-percent level 


\section{Table 2}

Investor-Only Momentum at the Fund Level

\begin{tabular}{|c|c|c|c|}
\hline & All Sample & Non-Crisis & Crisis \\
\hline Investor-Only: Fund Level & & & \\
\hline & & & $3.78^{* * *}$ \\
L0M & $1.99^{* * *}$ & $0.97^{* * *}$ & 4.30 \\
T-statistic & 5.49 & 3.55 & 46 \\
Observations & 127 & 81 & $0.63 * *$ \\
\hline L1M & & & 2.09 \\
\hline T-statistic & $0.54^{* * *}$ & $0.49^{*}$ & 43 \\
\hline
\end{tabular}

L0M is the point estimate for the mean lag-0 momentum trading measure. L1M is the point estimate for the mean lag-1 momentum trading measure (measured from return over the previous month). Investor-Only: Fund Level reflects only investor redemption effects at the fund level as in equation (4). All t-statistics are corrected for heteroskedasticity across funds. Full sample: quarterly data from April 1993 to January 1999. The crisis portion of the sample is December 1994-June 1995, July 1997-March 1998, August 1998-October 1998, and January 1999. The non-crisis portion is the rest of the sample. The total of roughly 127 observations is 13 funds times an average of about 10 quarters of available data per fund. For robustness, results in each cell are based only on observations within three standard deviations of the mean.

* Statistically Significant at the 10-percent level

** Statistically Significant at the 5-percent level

*** Statistically Significant at the 1-percent level 
Table 3

Momentum Trading Results by Crisis

\begin{tabular}{|c|c|c|c|}
\hline & Mexican Crisis & Asian Crisis & Russian Crisis \\
\hline \multicolumn{4}{|c|}{ Whole-Fund Momentum } \\
\hline $\begin{array}{c}\text { LOM } \\
\text { T-statistic } \\
\text { Observations }\end{array}$ & $\begin{array}{l}12.11^{* * * *} \\
3.45 \\
268\end{array}$ & $\begin{array}{l}1.69 * * * \\
2.97 \\
920\end{array}$ & $\begin{array}{l}8.26^{* * * *} \\
4.24 \\
417\end{array}$ \\
\hline $\begin{array}{c}\text { L1M } \\
\text { T-statistic } \\
\text { Observations }\end{array}$ & $\begin{array}{l}1.00 * \\
1.82 \\
297\end{array}$ & $\begin{array}{c}-0.25 \\
-0.69 \\
898\end{array}$ & $\begin{array}{l}0.22 \\
0.57 \\
413\end{array}$ \\
\hline \multicolumn{4}{|c|}{ Manager-Only Momentum } \\
\hline $\begin{array}{c}\text { L0M } \\
\text { T-statistic } \\
\text { Observations }\end{array}$ & $\begin{array}{l}6.56^{* *} \\
2.16 \\
279\end{array}$ & $\begin{array}{l}0.99 * * \\
2.32 \\
920\end{array}$ & $\begin{array}{l}1.04 \\
0.90 \\
412\end{array}$ \\
\hline $\begin{array}{c}\text { L1M } \\
\text { T-statistic } \\
\text { Observations }\end{array}$ & $\begin{array}{l}1.00 * * * \\
2.71 \\
297\end{array}$ & $\begin{array}{c}-0.17 \\
-0.74 \\
898\end{array}$ & $\begin{array}{c}-0.04 \\
-0.21 \\
414\end{array}$ \\
\hline \multicolumn{4}{|c|}{ Investor-Only Momentum } \\
\hline $\begin{array}{c}\text { L0M } \\
\text { T-statistic } \\
\text { Observations }\end{array}$ & $\begin{array}{l}7.56^{* *} \\
2.38 \\
284\end{array}$ & $\begin{array}{l}0.71 * * \\
2.30 \\
921\end{array}$ & $\begin{array}{l}6.86^{* * * *} \\
5.84 \\
426\end{array}$ \\
\hline $\begin{array}{c}\text { L1M } \\
\text { T-statistic } \\
\text { Observations }\end{array}$ & $\begin{array}{l}0.12 \\
0.34 \\
294\end{array}$ & $\begin{array}{c}0.00 \\
-0.02 \\
910\end{array}$ & $\begin{array}{l}0.64 \\
1.30 \\
398\end{array}$ \\
\hline
\end{tabular}

L0M is the point estimate for the mean lag-0 momentum trading measure. L1M is the point estimate for the mean lag-1 momentum trading measure (measured from return over the previous month). Whole-Fund momentum tests whether the mean of $\left(\Delta \mathrm{Q}_{\mathrm{j} t} \overline{\mathrm{Q}}_{\mathrm{ijt}}\right) \mathrm{R}_{\mathrm{jt} \mathrm{k}}$ is zero, per equation (1). Manager-Only momentum controls for investor redemption effects as in equation (2). Investor-Only momentum reflects only investor redemption effects as in equation (3). All t-statistics are corrected for heteroskedasticity across funds. The Mexican Crisis portion of the sample is December 1994-June 1995. The Asian Crisis portion of the sample is July 1997-March 1998. The Russian Crisis portion of the sample is August 1998-October 1998. For robustness, results in each cell are based only on observations within three standard deviations of the mean.

* Statistically Significant at the 10-percent level

** Statistically Significant at the 5-percent level

*** Statistically Significant at the 1-percent level 
Table 4

Contagion Trading Results

\begin{tabular}{|c|c|c|c|c|c|c|c|c|c|c|c|c|c|c|c|}
\hline \multicolumn{16}{|c|}{ Country/Regional Index } \\
\hline & \multicolumn{3}{|c|}{ Brazil } & \multicolumn{3}{|c|}{ Mexico } & \multicolumn{3}{|c|}{ Asia } & \multicolumn{3}{|c|}{ Russia } & \multicolumn{3}{|c|}{ U.S. } \\
\hline Statistics & $\begin{array}{l}\text { All } \\
\text { Sample }\end{array}$ & $\begin{array}{l}\text { Non- } \\
\text { Crisis }\end{array}$ & Crisis & $\begin{array}{l}\text { All } \\
\text { Sample }\end{array}$ & $\begin{array}{l}\text { Non- } \\
\text { Crisis }\end{array}$ & Crisis & $\begin{array}{l}\text { All } \\
\text { Sample }\end{array}$ & $\begin{array}{l}\text { Non- } \\
\text { Crisis }\end{array}$ & Crisis & $\begin{array}{l}\text { All } \\
\text { Sample }\end{array}$ & $\begin{array}{l}\text { Non- } \\
\text { Crisis }\end{array}$ & Crisis & $\begin{array}{l}\text { All } \\
\text { Sample }\end{array}$ & $\begin{array}{l}\text { Non- } \\
\text { Crisis }\end{array}$ & Crisis \\
\hline 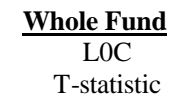 & $\begin{array}{l}1.80^{* * *} \\
3.45\end{array}$ & $\begin{array}{l}0.63 \\
1.06\end{array}$ & $\begin{array}{l}4.15^{* * * *} \\
3.00\end{array}$ & $\begin{array}{l}0.83^{* * * *} \\
2.56\end{array}$ & $\begin{array}{l}0.70 \\
1.63\end{array}$ & $\begin{array}{l}1.10^{*} \\
1.68\end{array}$ & $\begin{array}{l}0.72 * * \\
2.23\end{array}$ & $\begin{array}{l}0.39 * * * \\
2.79\end{array}$ & $\begin{array}{l}1.38 \\
1.38\end{array}$ & $\begin{array}{l}3.91 * * * \\
3.05\end{array}$ & $\begin{array}{l}2.48 \\
1.38\end{array}$ & $\begin{array}{l}6.18^{* * * *} \\
2.73\end{array}$ & $\begin{array}{l}-0.58 * * * \\
-2.81\end{array}$ & $\begin{array}{l}-0.25 \\
-1.08\end{array}$ & $\begin{array}{l}-1.26 * * * \\
-3.08\end{array}$ \\
\hline 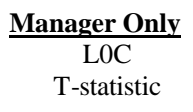 & $\begin{array}{l}0.09 \\
0.22\end{array}$ & $\begin{array}{l}-0.63 \\
-0.99\end{array}$ & $\begin{array}{l}1.52^{* * * *} \\
3.17\end{array}$ & $\begin{array}{l}0.02 \\
0.08\end{array}$ & $\begin{array}{l}-0.13 \\
-0.43\end{array}$ & $\begin{array}{l}0.32 \\
0.63\end{array}$ & $\begin{array}{l}0.53^{* *} \\
2.21\end{array}$ & $\begin{array}{l}0.12 \\
0.93\end{array}$ & $\begin{array}{l}1.36^{* * *} \\
2.15\end{array}$ & $\begin{array}{l}-0.59 \\
-0.66\end{array}$ & $\begin{array}{l}-1.26 \\
-1.05\end{array}$ & $\begin{array}{l}0.46 \\
0.29\end{array}$ & $\begin{array}{l}-0.50 * * * \\
-3.61\end{array}$ & $\begin{array}{l}-0.50 * * * \\
-2.90\end{array}$ & $\begin{array}{l}-0.51 * * * \\
-2.84\end{array}$ \\
\hline 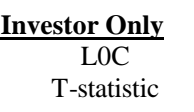 & $\begin{array}{l}1.89 * * * \\
3.95\end{array}$ & $\begin{array}{l}1.69 * * * \\
3.04\end{array}$ & $\begin{array}{l}2.30^{* * * *} \\
3.64\end{array}$ & $\begin{array}{l}1.12^{* * * *} \\
4.63\end{array}$ & $\begin{array}{l}0.92 * * * \\
3.23\end{array}$ & $\begin{array}{l}1.52 * * * \\
4.09\end{array}$ & $\begin{array}{l}0.62 * * * \\
2.58\end{array}$ & $\begin{array}{l}0.45 * * * \\
3.59\end{array}$ & $\begin{array}{l}0.96 \\
1.34\end{array}$ & $\begin{array}{l}5.87 * * * \\
4.70\end{array}$ & $\begin{array}{l}4.36^{* * * *} \\
2.88\end{array}$ & $\begin{array}{l}8.28^{* * * *} \\
4.43\end{array}$ & $\begin{array}{l}-0.02 \\
-0.09\end{array}$ & $\begin{array}{l}0.21 \\
1.15\end{array}$ & $\begin{array}{l}-0.48 \\
-1.27\end{array}$ \\
\hline
\end{tabular}

LOC denotes lag-0 contagion trading. Whole-Fund contagion tests whether the mean of $\left(\Delta \mathrm{Q}_{\mathrm{j} t} / \overline{\mathrm{Q}}_{\mathrm{ijt}}\right) \mathrm{R}_{\mathrm{ft}}$ is zero, where $\mathrm{R}_{\mathrm{ft}}$ is the return on foreign index f from t-1 to t, with $\mathrm{f} \in\{$ Brazil, Mexico, Asia, Russia, $\mathrm{U} . \mathrm{S}$. $\}$, per equation (4). Manager-Only contagion controls for investor redemption effects as in equation (5). Investor-Only contagion reflects only investor redemption effects as in equation (6). All t-statistics are corrected for heteroskedasticity across funds. Full sample: April 1993 to January 1999. The crisis portion of the sample is December 1994-June 1995, July 1997-March 1998, August 1998-October 1998, and January 1999. The non-crisis portion is the rest of the sample. Asia is the IFC Asia Stock Market Index. Note that Brazilian equities are excluded from the calculation of L0C for Brazil (similarly for Mexico).

* Statistically Significant at the 10-percent level

** Statistically Significant at the 5-percent level

**** Statistically Significant at the 1-percent level 
Table 5

Contagion Trading Results by Individual Crisis

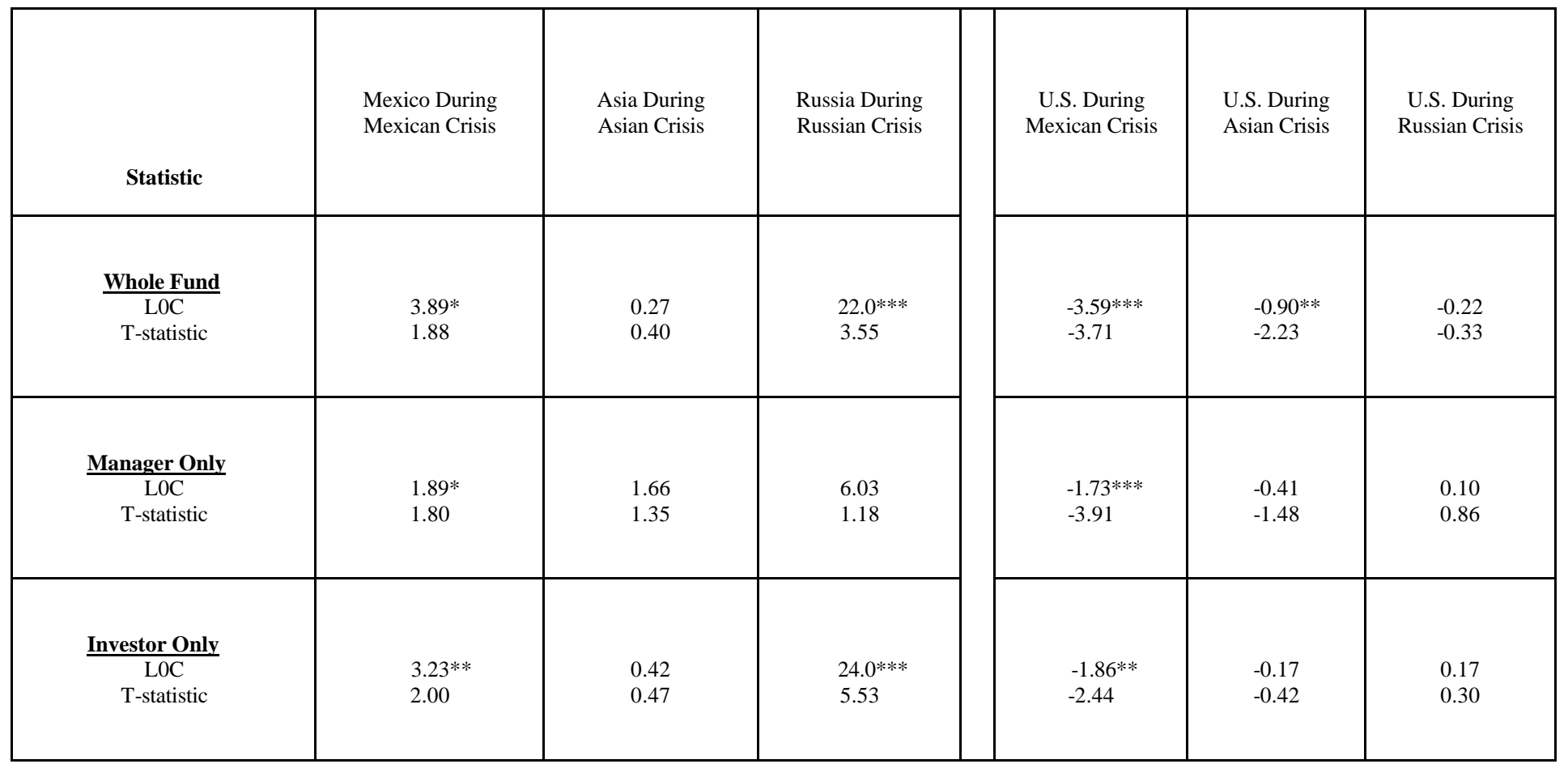

L0C denotes lag-0 contagion trading. Whole-Fund contagion tests whether the mean of $\left(\Delta \mathrm{Q}_{\mathrm{jt}} / \overline{\mathrm{Q}}_{\mathrm{ijt}}\right) \mathrm{R}_{\mathrm{ft}}$ is zero, where $\mathrm{R}_{\mathrm{ft}}$ is the return on foreign index f from t-1 to t, with $\mathrm{f} \in\{$ Mexico, Asia, Russia, $\mathrm{U}$.S. $\}$, per equation (4). Manager-Only contagion controls for investor redemption effects as in equation (5). Investor-Only contagion reflects only investor redemption effects as in equation (6). All t-statistics are corrected for heteroskedasticity across funds. The Mexican Crisis portion of the sample is December 1994-June 1995. The Asian Crisis portion of the sample is July 1997-March 1998. The Russian Crisis portion of the sample is August 1998-October 1998. Asia is the IFC Asia Stock Market Index. Note that Mexican equities are excluded from the calculation of L0C for Mexico.

* Statistically Significant at the 10-percent level

** Statistically Significant at the 5-percent leve

*** Statistically Significant at the 1-percent leve 
Table 6: Variance Ratio Test of Stock Returns

\begin{tabular}{|l|cccccc|}
\hline & \multicolumn{7}{c|}{ Horizon } \\
\hline COUNTRY & 3-months & 12 -months & 24-months & 36-months & 48 -months & 60 -months \\
\hline Argentina & 1.02 & 0.88 & 0.70 & 0.62 & 0.60 & 0.60 \\
& $(0.84)$ & $(0.59)$ & $(0.35)$ & $(0.35)$ & $(0.39)$ & $(0.45)$ \\
Brazil & 1.01 & 0.99 & 0.82 & 0.71 & 0.75 & 0.83 \\
& $(0.93)$ & $(0.95)$ & $(0.57)$ & $(0.46)$ & $(0.59)$ & $(0.75)$ \\
Chile & 1.34 & 1.94 & 2.50 & 2.88 & 3.16 & 2.97 \\
& $(0.00)$ & $(0.00)$ & $(0.00)$ & $(0.00)$ & $(0.00)$ & $(0.00)$ \\
Colombia & 1.43 & 2.22 & 2.40 & 2.63 & 2.76 & 2.81 \\
& $(0.00)$ & $(0.00)$ & $(0.00)$ & $(0.00)$ & $(0.00)$ & $(0.00)$ \\
Mexico & 1.31 & 1.50 & 1.61 & 1.74 & 1.85 & 1.84 \\
& $(0.00)$ & $(0.02)$ & $(0.06)$ & $(0.06)$ & $(0.07)$ & $(0.11)$ \\
Peru & 1.07 & 0.80 & 0.64 & 0.70 & 0.82 & 0.58 \\
& $(0.45)$ & $(0.37)$ & $(0.27)$ & $(0.45)$ & $(0.69)$ & $(0.42)$ \\
Venezuela & 1.15 & 1.59 & 1.53 & 1.10 & 0.97 & 0.88 \\
& $(0.09)$ & $(0.01)$ & $(0.10)$ & $(0.80)$ & $(0.95)$ & $(0.82)$ \\
& 0.96 & 0.91 & 0.83 & 0.90 & 0.91 & 0.94 \\
& $(0.64)$ & $(0.69)$ & $(0.60)$ & $(0.81)$ & $(0.84)$ & $(0.91)$ \\
\hline
\end{tabular}

P-values shown in parentheses for the null hypothesis that the variance ratio equals 1 , where the numerator is the variance of $\mathrm{k}$-month returns and the denominator is $\mathrm{k}$ times the variance of 1 -month returns. If returns follow a random walk (i.e., no return autocorrelation), then return variance is a linear function of horizon length: the variance of returns over $\mathrm{k}$ periods is $\mathrm{k}$ times the variance of returns over one-period. If returns are positively autocorrelated, the variance of k-period returns is larger than the sum of one-period returns-variances grow faster than linearly. Thus, variance ratios larger than one are consistent with rational positive momentum trading. Alternatively, when returns are negatively autocorrelated, the variance of k-period returns is smaller than $\mathrm{k}$ times the variance of one-period returns. Variance ratios smaller than one would call for negative momentum (or contrarian) trading. Sample: monthly index returns from January 1975 to October 1998. 


\section{Table A1}

Regression Results: Whole Fund

$\left(\frac{Q_{i, j, t}-Q_{i, j, t-1}}{\bar{Q}_{i, j, t}}\right)=\alpha+\beta_{1} R_{j, t}+\beta_{2} R_{j, t-1}+\beta_{3} R_{L A, t}+\beta_{4} R_{L M, t}+\beta_{5} R_{U S, t}+\varepsilon_{i, j, t}$

\begin{tabular}{|c|c|c|c|}
\hline Independent Variables & All Sample & Non-Crisis & Crisis \\
\hline $\begin{array}{c}\text { Own Return }\left(\beta_{1}\right) \\
\text { T-statistic }\end{array}$ & $\begin{array}{l}0.0021^{* * *} \\
5.34\end{array}$ & $\begin{array}{l}0.0029 * * * \\
4.04\end{array}$ & $\begin{array}{l}0.0015^{* * *} \\
2.76\end{array}$ \\
\hline $\begin{array}{c}\text { Own Return Lagged }\left(\beta_{2}\right) \\
\text { T-statistic }\end{array}$ & $\begin{array}{l}0.0029 * * * \\
3.15\end{array}$ & $\begin{array}{l}0.0042^{* * *} \\
5.501\end{array}$ & $\begin{array}{l}0.0002 \\
0.138\end{array}$ \\
\hline $\begin{array}{c}\text { Latin America Return }\left(\beta_{3}\right) \\
\text { T-statistic }\end{array}$ & $\begin{array}{l}0.0035^{* * *} \\
3.20\end{array}$ & $\begin{array}{l}0.0021 \\
1.49\end{array}$ & $\begin{array}{l}0.0041^{* * *} \\
2.62\end{array}$ \\
\hline $\begin{array}{c}\text { Local Index Return }\left(\beta_{4}\right) \\
\text { T-statistic }\end{array}$ & $\begin{array}{l}0.0000 \\
-0.01\end{array}$ & $\begin{array}{l}-0.0003 \\
-0.32\end{array}$ & $\begin{array}{l}0.0006 \\
0.44\end{array}$ \\
\hline $\begin{array}{c}\text { US Return }\left(\beta_{5}\right) \\
\text { T-statistic }\end{array}$ & $\begin{array}{l}-0.0065^{* * * *} \\
-6.24\end{array}$ & $\begin{array}{l}-0.0041^{*} \\
-1.95\end{array}$ & $\begin{array}{l}-0.0096^{* * *} \\
-4.54\end{array}$ \\
\hline $\begin{array}{l}\text { Constant } \\
\text { T-statistic }\end{array}$ & $\begin{array}{l}-0.0048 \\
-0.24\end{array}$ & $\begin{array}{l}-0.0086 \\
-0.30\end{array}$ & $\begin{array}{l}0.0026 \\
0.05\end{array}$ \\
\hline $\begin{array}{c}\text { Observations } \\
\text { Adjusted R-squared }\end{array}$ & $\begin{array}{c}4,842 \\
0.05\end{array}$ & $\begin{array}{c}3,223 \\
0.03\end{array}$ & $\begin{array}{c}1,619 \\
0.06\end{array}$ \\
\hline
\end{tabular}

These results are "Whole Fund" in that they include no control for investor redemption effects as in equation (7). T-statistics are corrected for heteroskedasticity across funds. Full sample: April 1993 to January 1999. The crisis portion of the sample is December 1994-June 1995, July 1997-March 1998, August 1998-October 1998, and January 1999. The non-crisis portion is the rest of the sample. For robustness, results in each cell are based only on observations within three standard deviations of the mean.

* Statistically Significant at the 10-percent level

** Statistically Significant at the 5-percent level

*** Statistically Significant at the 1-percent level 


\section{Table A2}

\section{Regression Results: Manager Only}

$$
\left(\frac{Q_{i, j, t}-Q_{i, j, t-1}}{\bar{Q}_{i, j, t}}-\frac{\sum_{j \in i}\left(Q_{i, j, t}-Q_{i, j, t-1}\right) \bar{P}_{j, t}}{\sum_{j \in i} \bar{Q}_{i, j, t} \bar{P}_{j, t}}\right)=\alpha+\beta_{1} R_{j, t}+\beta_{2} R_{j, t-1}+\beta_{3} R_{L A, t}+\beta_{4} R_{L M, t}+\beta_{5} R_{U S, t}+\varepsilon_{i, j, t}
$$

\begin{tabular}{|c|c|c|c|}
\hline Independent Variables & All Sample & Non-Crisis & Crisis \\
\hline $\begin{array}{c}\text { Own Return }\left(\beta_{1}\right) \\
\text { T-statistic }\end{array}$ & $\begin{array}{l}0.0042^{* * * *} \\
5.56\end{array}$ & $\begin{array}{l}0.0052^{* * * *} \\
3.76\end{array}$ & $\begin{array}{l}0.0033^{* * *} \\
2.76\end{array}$ \\
\hline $\begin{array}{c}\text { Own Return Lagged }\left(\beta_{2}\right) \\
\text { T-statistic }\end{array}$ & $\begin{array}{l}0.0049 * * * \\
2.78\end{array}$ & $\begin{array}{l}0.0071^{* * *} \\
4.04\end{array}$ & $\begin{array}{l}0.0004 \\
0.17\end{array}$ \\
\hline $\begin{array}{c}\text { Latin America Return }\left(\beta_{3}\right) \\
\text { T-statistic }\end{array}$ & $\begin{array}{l}0.0014 \\
1.17\end{array}$ & $\begin{array}{l}-0.0001 \\
-0.44\end{array}$ & $\begin{array}{l}0.004 * * * \\
3.46\end{array}$ \\
\hline $\begin{array}{l}\text { Local Index Return }\left(\beta_{4}\right) \\
\text { T-statistic }\end{array}$ & $\begin{array}{l}-0.0004 \\
-0.328\end{array}$ & $\begin{array}{l}-0.0011 \\
-0.55\end{array}$ & $\begin{array}{l}0.0011 \\
0.48\end{array}$ \\
\hline $\begin{array}{l}\text { US Return }\left(\beta_{5}\right) \\
\text { T-statistic }\end{array}$ & $\begin{array}{l}-0.0115^{* * * *} \\
-6.54\end{array}$ & $\begin{array}{l}-0.0063^{* * *} \\
-2.90\end{array}$ & $\begin{array}{l}-0.0196^{* * *} \\
-7.018\end{array}$ \\
\hline $\begin{array}{l}\text { Constant } \\
\text { T-statistic }\end{array}$ & $\begin{array}{l}0.0108 \\
0.326\end{array}$ & $\begin{array}{l}-0.0155 \\
-0.40\end{array}$ & $\begin{array}{l}0.0970^{* *} \\
2.53\end{array}$ \\
\hline $\begin{array}{c}\text { Observations } \\
\text { Adjusted R-squared }\end{array}$ & $\begin{array}{c}4,942 \\
0.03\end{array}$ & $\begin{array}{c}3,274 \\
0.02\end{array}$ & $\begin{array}{c}1,668 \\
0.05\end{array}$ \\
\hline
\end{tabular}

These results are "Manger Only" in that they control for investor redemption effects as in equation (8). T-statistics are corrected for heteroskedasticity across funds. Full sample: April 1993 to January 1999. The crisis portion of the sample is December 1994-June 1995, July 1997-March 1998, August 1998-October 1998, and January 1999. The non-crisis portion is the rest of the sample. For robustness, results in each cell are based only on observations within three standard deviations of the mean.

* Statistically Significant at the 10-percent level

** Statistically Significant at the 5-percent level

*** Statistically Significant at the 1-percent level 


\section{Table A3}

Regression Results: Investor Only

$$
\left(\frac{\sum_{j \in i}\left(Q_{i, j, t}-Q_{i, j, t-1}\right) \bar{P}_{j, t}}{\sum_{j \in i} \bar{Q}_{i, j, t} \bar{P}_{j, t}}\right)=\alpha+\beta_{1} R_{j, t}+\beta_{2} R_{j, t-1}+\beta_{3} R_{L A, t}+\beta_{4} R_{L M, t}+\beta_{5} R_{U S, t}+\varepsilon_{i, j, t}
$$

\begin{tabular}{|c|c|c|c|}
\hline Independent Variables & All Sample & Non-Crisis & Crisis \\
\hline $\begin{array}{c}\text { Own Return }\left(\beta_{1}\right) \\
\text { T-statistic }\end{array}$ & $\begin{array}{l}-0.0001 \\
-0.84\end{array}$ & $\begin{array}{l}0.0001 \\
1.13\end{array}$ & $\begin{array}{l}-0.0001 \\
-0.45\end{array}$ \\
\hline $\begin{array}{c}\text { Own Return Lagged }\left(\beta_{2}\right) \\
\text { T-statistic }\end{array}$ & $\begin{array}{l}0.0007 \\
1.36\end{array}$ & $\begin{array}{l}0.0004 \\
0.76\end{array}$ & $\begin{array}{l}0.0018 \\
1.69\end{array}$ \\
\hline $\begin{array}{c}\text { Latin America Return }\left(\beta_{3}\right) \\
\text { T-statistic }\end{array}$ & $\begin{array}{l}0.0037 * * * \\
6.62\end{array}$ & $\begin{array}{l}0.0039 * * * \\
4.45\end{array}$ & $\begin{array}{l}0.0022^{*} \\
1.66\end{array}$ \\
\hline $\begin{array}{c}\text { Local Index Return }\left(\beta_{4}\right) \\
\text { T-statistic }\end{array}$ & $\begin{array}{l}0.0011 * * * \\
3.83\end{array}$ & $\begin{array}{l}0.0012 * * * \\
5.02\end{array}$ & $\begin{array}{l}0.0005 \\
0.94\end{array}$ \\
\hline $\begin{array}{c}\text { US Return }\left(\beta_{5}\right) \\
\text { T-statistic }\end{array}$ & $\begin{array}{l}-0.0021 \\
-1.26\end{array}$ & $\begin{array}{l}-0.0034 \\
-1.48\end{array}$ & $\begin{array}{l}0.0013 \\
0.33\end{array}$ \\
\hline $\begin{array}{l}\text { Constant } \\
\text { T-statistic }\end{array}$ & $\begin{array}{l}0.0094 \\
0.52\end{array}$ & $\begin{array}{l}0.0247 \\
0.94\end{array}$ & $\begin{array}{l}-0.0562 \\
-1.18\end{array}$ \\
\hline $\begin{array}{c}\text { Observations } \\
\text { Adjusted R-squared }\end{array}$ & $\begin{array}{l}4790 \\
0.29\end{array}$ & $\begin{array}{l}3241 \\
0.21\end{array}$ & $\begin{array}{l}1549 \\
0.19\end{array}$ \\
\hline
\end{tabular}

These results are "Investor Only" in that they reflect only investor redemption effects as in equation (9). T-statistics are corrected for heteroskedasticity across funds. Full sample: April 1993 to January 1999. The crisis portion of the sample is December 1994-June 1995, July 1997-March 1998, August 1998-October 1998, and January 1999. The non-crisis portion is the rest of the sample. For robustness, results in each cell are based only on observations within three standard deviations of the mean.

* Statistically Significant at the 10-percent level

** Statistically Significant at the 5-percent level

*** Statistically Significant at the 1-percent level 


\section{References}

Asness, C., J. Liew, and R. Stevens, 1997, "Parallels Between the Cross-Sectional Predictability of Stock and Country Returns," Journal of Portfolio Management, 3: 79-87.

Bohn, H., and L. Tesar, 1996, "US Equity Investment in Foreign Markets: Portfolio Rebalancing or Return Chasing?" American Economic Review, 86: 77-81.

Brown, S., W. Goetzmann, and J. Park, 1998, "Hedge Funds and the Asian Currency Crisis of 1997," NBER Working Paper 6427, February.

Calvo, G., 1999, "Contagion in Emerging Markets: When Wall Street Is a Carrier," University of Maryland working paper.

Calvo, G., and E. Mendoza, 1998, "Rational Herd Behavior and the Globalization of Securities Markets," University of Maryland working paper.

Campbell, J., A. Lo, and C. MacKinlay, 1997, The Econometrics of Financial Markets, Princeton University Press, Princeton, New Jersey.

Choe, H., B. Kho, and R. Stulz, 1999, "Do Foreign Investors Destabilize Stock Markets? The Korean Experience in 1997," typescript, Ohio State University, January.

Corsetti, G., P. Pesenti, and N. Roubini, 1998, "What Caused the Asian Currency and Financial Crisis?" typescript, New York University, March.

De Bondt, W., and R. Thaler, 1985, "Does the Stock Market Overreact?" Journal of Finance, 40: 793-805.

Eichengreen, B., and D. Mathieson, 1998, "Hedge Funds and Financial Market Dynamics," Occasional Paper No. 166.

Eichengreen, B, A. Rose, and C. Wyplosz, 1996, "Contagious Currency Crises," NBER working paper No. 5681.

Forbes, K., and R. Rigobon, 1998, "No Contagion, Only Interdependence: Measuring Stock Market Co-movements," NBER Working Paper \#7267, September.

Frankel, J., and S. Schmukler, 1998, "Crisis, Contagion, and Country Funds," in R. Glick, ed., Managing Capital Flows and Exchange Rates (Cambridge University Press).

Froot, K., P. O'Connell, and M. Seasholes, 1998, “The Portfolio Flows of International Investors, I," forthcoming, Journal of Financial Economics.

Grinblatt, M., S. Titman, and R. Wermers, 1995, "Momentum Investment Strategies, Portfolio Performance, and Herding: A Study of Mutual Fund Behavior," American Economic Review, 85, 1088-1105.

Jegadeesh, N., 1990, "Evidence of Predictable Behavior of Security Returns," Journal of Finance, 45: 881-898.

Jegadeesh, N. and S. Titman, 1993, "Returns to Buying Winners and Selling Losers: Implications for Stock Market Efficiency," Journal of Finance, 48, 1.

Kaminsky, G., 1998, "Currency and Banking Crises: The Early Warnings of Distress," International Finance Discussion Paper No. 629, Board of Governors of the Federal Reserve System.

Kaminsky, G. and C. Reinhart, 1999, "On Crises, Contagion, and Confusion," George Washington University Working Paper, forthcoming Journal of International Economics. 
Kaminsky, G. and S. Schmukler, 1999, "What Triggers Market Jitters? A Chronicle of the Asian Crisis," Journal of International Money and Finance, Vol. 18, No. 4.

Kim, W., and S. Wei, 1999, "Foreign Portfolio Investors Before and During a Crisis," NBER Working Paper No. 6968, February.

Kodres, L., and M. Pritsker, 1999, "A Rational Expectations Model of Financial Contagion," typescript, International Monetary Fund and Board of Governors of the Federal Reserve System, May.

Lehmann, B., 1990, "Fads, Martingales, and Market Efficiency," Quarterly Journal of Economics, 105: 1-28.

Marcis, R., S. West, and V. Leonard-Chambers, 1995, "Mutual Fund Shareholder Response to Market Disruptions," Perspective, Investment Company Institute, Vol. 1 , No. 1.

Rea, J., 1996, "U.S. Emerging Market Funds: Hot Money or Stable Source of Investment Capital?" Perspective, Investment Company Institute, Vol. 2, No. 6.

Rouwenhorst, Geert, 1998, "International Momentum Strategies," Journal of Finance, $53,267-284$.

Tesar, L., and I. Werner, 1994, "International Equity Transactions and U.S. Portfolio Choice," in J. Frankel (ed.), The Internationalization of Equity Markets, University of Chicago Press, 185-220.

Valdes, Rodrigo, 1998, "Emerging Markets Contagion: Evidence and Theory," Banco Central de Chile, typescript, May.

Warther, V., 1995, "Aggregate Mutual Fund Flows and Security Returns," Journal of Financial Economics, 39: 209-235.

Wermers, R., 1999, "Mutual Fund Herding and the Impact on Stock Prices," Journal of Finance, 54: 581-622. 